fields for cultivation into squares and the straightness of the field drains, ranging from eight to ten feet in depth, the mode of burial in the open in wooden coffins surrounded by a picket fence, and the nonPapuan character of the people, shown especially in the lightness of their colour, their high cheekbones and finely moulded features. It is stated that, while anthropologists hesitate to expross any opinion, owing to the lack of confirmation on investigation of previously reported marvels from the interior of Papua, Mr. E. W. P. Chinnory, Government anthropologist of Papua, has suggested their identity with the unknown tribes of Mount Hagen discovered in 1932 by Messrs. J. L. Taylor and M. Leahy (see Nature, 134, 328; 1934). Mr. Hides, however, maintains that he has discovered a new people, but identifies tribes whom he afterwards encountered to the south-east with the people of Mount Hagen. His own theory is that the light-skinned people escaped years ago up the limestone cliffs after defeat in battle by other tribes and, discovering this fertile valley, settled, multiplied, and developed an entirely selfcontained community. Until photographs are available, no judgment is possible, and until much more is known of the physical characters of the inhabitants of Papua, there is little utility in the discussion of theories of the survival of races. In the meantime Mr. Leahy and his brother confidently claim priority of discovery, and assert that light-skinned natives, common to many tribes, are pathological cases and usually exhibit symptoms of a mild form of St. Vitus's dance. Mr. M. Leahy, it is reported, is now on his way to submit photographs, films and other data to the Royal Geographical Society.

\section{The Ovada Disaster}

ONE of those calamitous occurrences which, from time to time, show the fallibility of human judgment in constructional work, has plunged northern Italy into desolation and mourning. Shortly after noon on August 13, a dam, which formed in the valley of the River Orba in Piedmont near the town of Ovada, the artificial lake, or reservoir, of Orsiglieto, containing a volume of $78,000,000$ cubic feet of water, suddenly gave way and the impounded water, thus released, swept through the valley, destroying entire villages and causing widespread havoc and destruction. The number of lives lost is probably several hundred, and has been put so high as a thousand; but, in the absence of official statement, this estimate should, perhaps, be accepted with reserve. Four bridges were broken, one of them a railway bridge which collapsed a few minutes after a passenger train had passed over it. Nearly two miles of track has been torn up. The other three bridges were highway structures. Traffic was cut off, and telephonic and telegraphic communications interrupted. The flooded zone extended over an area about $2 \frac{1}{2}$ miles long and $1 \frac{1}{2}$ miles wide. It is stated that the disaster was the culmination of a series of violent thunderstorms which broke over southern Piedmont and central Liguria during the night of August 12 and the morning of August 13, and that in the Ovada region, adjacent to the dam, the precipitation reached the intensity of a 'cloudburst', converting streams and watercourses into raging torrents. The damage is roughly estimated in the neighbourhood of a million sterling. The dam, which is part of the undertaking of the Genoa Electrical Co., was built twenty years ago. Official instructions have been issued for its reconstruction.

\section{Sir John Colbatch}

UNDER the title of "An Early Forgotten Antiseptic Surgeon", who, as he maintains, has been most unjustifiably neglected by surgeons and medical historians, Prof. D. F. Fraser-Harris (Med. Press and Circ., June 19, pp. 580-82) gives an account of John Colbatch, the author of a work published in 1704 entitled "Novum lumen chirurgieum or a New Light of Surgery wherein is Discovered a much more Safe and Speedy way of Curing Wounds than has hitherto been Practised". In this book, Colbatch describes the virtues of a "vulnerary powder", with which he had dressed wounds so successfully that in about four days all putrefaction was stopped. The composition of the powder he kept secret, and thereby incurred the reputation of a quack; but his comparison of its odour to the smell of roses suggested to Sir Watson Cheyne that it was ammonium salicylate. The chief scientific interest of Colbatch's work lies in the fact that, in addition to relating in detail the histories of fourteen cases of severe wounds in Flanders, where he was on military service, treated by the powder, he states that he performed experiments on about a hundred dogs to test its value, and was thus one of the earliest surgeons to experiment in the modern sense of the term. The date of Colbatch's birth is uncertain, but he died at an advanced age on January 15, 1729. He was knighted by George I in 1716 .

\section{Work of the Mellon Institute}

THe twenty-second annual report of the Mellon Institute of Industrial Research, covering the period 1934-35, refers to extending activities in scientific, as well as in industrial, research. It is expected that the new building will be gradually occupied during 1935 and be complete by the end of the year. 62 industrial fellowships were in operation during 1934, requiring the services of 97 fellows and 48 assistants. 56 of these fellowships were in operation at the end of the year, and a high proportion of the fellowships are of five or more years standing. New fellowships during the year dealt with starch, stone, dried yeast, soya bean, etc., while fellowships terminated during the year covered cleaning, sugar, velvet, phosphates, paper finishing and vanadium. Special attention is directed to the studies on cinchona alkaloids conducted by the Department of Research in Pure Chemistry with the object of discovering compounds of therapeutic value in pneumonia. Fifty-nine such preparations have been tested, and biological and clinical data are being accumulated, some of which have been published. Studies on the preparation of apoquinine and its ethyl and hydroxyethyl ether are 